\title{
Teachers' Professional Development Coaching Based on Islamic Boarding School Culture
}

\author{
Eli Masnawati $^{1{ }^{* *}, \text { Ibrahim Bafadal }}{ }^{2}$, Ali Imron ${ }^{2}$, Achmad Supriyanto ${ }^{2}$ \\ ${ }^{1}$ STKIP PGRI Bangkalan, Indonesia \\ ${ }^{2}$ Educational Management, State University of Malang, Indonesia
}

Copyright $(2019$ by authors, all rights reserved. Authors agree that this article remains permanently open access under the terms of the Creative Commons Attribution License 4.0 International License

\begin{abstract}
This article aims at describing the process of teachers' professional development based on Islamic boarding school culture including pattern of interaction in teacher training, approaches to teacher development, stakeholder involvement in teacher training, supervision and evaluation of the implementation of teacher training based on Islamic boarding schools. This research was conducted employing comparative inductive data analysis, multi-site design, and qualitative approach. This research found there are five interaction patterns used for development namely: interaction pattern of once-in-a-month regular recitation, the interaction pattern of imtikhan, interaction pattern of congregational prayers, interaction pattern of get-together (silahturahmi), interaction pattern of once-in-a-month regular meetings. And Secondly, it is about the four approaches in professional development namely: In-Group approach, individual approach, seniority approach, and Islamic boarding school bureaucracy approach. And Thirdly, the stakeholder involvement in the coaching namely: Social figure (the head of the village), school committee, UTM (Universitas Truno Joyo) Bangkalan lecturers, the headmaster of Junior High School 2 Kamal, school supervisors. Fourth, supervision and evaluation namely: the administers of supervisor and evaluation are the chairman of the foundation, headmaster, vice principal, Islamic boarding school coach, school supervisor, five senior teachers and school committee.
\end{abstract}

Keywords Coaching, Teachers, Islamic Boarding School

\section{Introduction}

The general provision of the Republic of Indonesia Act article 1 no. 14 Year 2005 states that teachers are professional educators whose duties are educating, teaching, and coaching to direct, give training, and assess as well as evaluate their students [1]. As aforementioned, it is clearly stated that teachers are professional educators and must own teaching certificate. Certification is only one part of professional values for a teacher, what is important is the teacher's performance has a competence which shows and proves a teacher's professionalism [2].

Teachers' professionalism both quantitatively and qualitatively cannot be merely formed without a professional development coaching, which is very beneficial; one of them is by administering coaching and mentoring. Coaching and mentoring programs are given to the teachers with aims at assisting teachers who have weaknesses and shortcomings in terms of performance during conducting their teaching profession or teaching their students. Both senior and junior teachers who encounter weaknesses and shortcomings in conducting the profession are responsible for doing the improvement. The headmaster is the responsible leader to do mentoring and coaching for teachers as their subordinates who encounter weakness and shortcomings in conducting the profession in teaching. The mentoring and coaching to improve the teachers' professionalism is an effort to increase the teachers' competency from the aspect of Human Resource Management (HRM) in which very crucial to be conducted the process of HRM planning.

Besides conducting coaching and mentoring to motivate teachers in improving their professionalism, compensation, award, education, and conducting training are needed for teacher competency development. The punishment is given to the teacher if the teacher experiences problems that cannot be changed even after the mentoring and coaching are conducted. The teacher will be dismissed so that they will not harm the students and school organization to develop the teacher professional competence conducted both individually and in-group. The teacher professionalism mentoring and coaching need to involve external supervisors from educational offices and the Ministry of Religion since it can affect positively in developing the Baya'gub teachers' professionalism [3].

The administration of coaching and teaching to teachers 
is conducted by the headmaster, the chairman of the foundation, peers who have seniority in terms of competence. The school supervisors also conduct coaching and mentoring for teachers who have weaknesses and shortcomings during the teaching process. There are three aspects of planning in conducting the coaching for teachers' competence, they are (1) problem diagnosis (2) conducting a planning for coaching strategy (3) preparing some supportive documents in coaching, authority, and responsibility for coaching is held by the headmaster of the Islamic school who also leads or the chairman of the Islamic boarding school foundation. The coaching includes the efforts of improving the academic competence qualification; management of teacher certification, material training that is integrated with competency material related to teacher professionalism in monitoring. In addition, coaching also requires supervision activities. The administration of coaching is based on the Sunnah of the Prophet Muhammad shâllahu alaihi wassalam in performing the tradition of al-salaf as-shâlih. Furthermore, the coaching needs a result evaluation from the evaluation as the necessary follow up for improvement during the coaching [4].

Rizal [5] argue that the pattern of coaching in the Islamic boarding school has been running in the path of Islamic boarding school culture, whereas using coaching is an alternative amid modernity and globalization of information and technology in the education world. The teachers, who are expected by the Indonesian nation to become professional teachers in the region of Islamic boarding school with local wisdom, survive, and show relatively good results.

That the coaching pattern in the Islamic boarding school has been running in the Islamic boarding schools culture during the coaching is an alternative amid modernity and globalization of information and technology in the world of education. The teachers aspired by the Indonesian people to become professional teachers in the Islamic boarding school environment with "local wisdom," which survives and shows relatively better results. The integration between school culture and the developed Islamic boarding school culture includes; (1) providing the needs of motivation and needs for achievement, (2) encouraging high discipline, (3) a sense of family and friendship togetherness, (4) obedience in carrying out the system and rules, (5) congregational prayer is an obligation to be maintained, (6) disseminate and conduct the behavior of studying (7) prioritizing the aspect of respecting each other.

This research is very interesting in terms of exploring the interaction pattern in coaching the teachers based on the Islamic boarding school culture employing approaches in coaching, the extent of stakeholder involvement in teacher coaching and the implementation of supervision and evaluation in teacher development based on Islamic boarding school culture. So far, it is known that the world of Islamic boarding school which has a strong culture and system full of independence and high consistency. It is a community with its main elements namely kiai (Islamic cleric), santri (Islamic students), mosque, hut, and yellow book is a separate sub-culture despite the modernization and globalization, the Islamic boarding school environment remains as an educational institution that can play a role and colour the world of education in Indonesia. Zuhriy [2] argue that Islamic boarding school education is the forerunner of formal education in Indonesia until now it can survive and still exist. The role of the cleric is to do tabligh or da'wah and develop the world of education, the clerics preach to do Quranic recitation, the study of the yellow scriptures, interpretations, hadith, khitobah, recitation of tahlil, yasin, shlawat, barjanzian, and other religious activities. In the educational field, clerics participate as teachers of religious education in Islamic schools across educational levels, namely Madrasah Ibtidaiyah, Tsanawiyah, Aliyah, and vocational schools [6].

The Republic of Indonesia Department of Religion (2004) states that there are several factors affecting the success in the Islamic boarding school environment namely (1) Salafiyah, (2) systematic management and high discipline, (3) diverse and applicable education, (4) having a charismatic and responsive leader, (5) success of alumni, (6) trust and support from students, alumni, guardians, and community in the Islamic boarding school environment towards the existence of the Islamic boarding school [7]. The function of Islamic boarding school reflects the characteristics from the aspects of leadership and independence; they are (1) Islamic boarding school as the transformation institute of Islamic studies, (2) social control, and (3) social engineering [7].

Sulaiman [8] describes there are three main functions of Islamic boarding school which give characteristics of Islamic boarding school (diniyah) related to various kinds of religion (ijtimaiyah), social control form, and administration of education (tarbawiyah). The diversity of roles and functions of Islamic boarding school currently is a meaningful, interesting, and unique phenomenon as an effort to determine patterns and functions for the development of education. The education world in the Islamic boarding school environment has the advantages of roles in the society, particularly emphasizing the priorities of fostering the living norm values related to the administration of religious teaching practices and national moral education which are different and incomparable to other institution outside the Islamic boarding school.

The problems about teacher professional development coaching based on the Islamic boarding school culture are interesting and unique to be discussed with diverse issues needed to be solved by the chairman of the foundation and administrators at the Islamic boarding schools. This article aims at describing the process of teacher professional 
development based on Islamic boarding school culture including (1) pattern of interaction in teacher training based on pesantren culture, (2) approaches to teacher development based on pesantren culture, (3) stakeholder involvement in teacher training based on Islamic boarding schools, (4) supervision and evaluation of the implementation of teacher training based on Islamic boarding schools.

\section{Methods}

This research used a qualitative approach with multi-site studies and analytic induction method. According to Bogdan and Biklen [9] explained that researchers conducted data collection and processing, which intends to develop the theory and testing by having the feasibility of the multi-site design, as seen in Table 1.

Table 1. The comparison of 3-site background characteristics

\begin{tabular}{|c|c|c|c|c|}
\hline No. & Aspects of comparison & $\begin{array}{c}\text { Nurudholam Junior High } \\
\text { School }\end{array}$ & $\begin{array}{c}\text { Ngadisari Junior High } \\
\text { School }\end{array}$ & $\begin{array}{l}\text { Baburrahma Islamic } \\
\text { Junior High School }\end{array}$ \\
\hline 1. & $\begin{array}{l}\text { Educational institution under } \\
\text { the Islamic boarding school }\end{array}$ & $\begin{array}{c}\text { Nurudholam Islamic } \\
\text { boarding school }\end{array}$ & $\begin{array}{c}\text { Ngadisari Nurul Iman Islamic } \\
\text { boarding school }\end{array}$ & $\begin{array}{c}\text { Baburohmah Islamic } \\
\text { boarding school }\end{array}$ \\
\hline 2. & Structure of the organization & $\begin{array}{l}\text { Chairman of the } \\
\text { foundation, headmaster, } \\
\text { vice principal, teachers. }\end{array}$ & $\begin{array}{l}\text { Chairman of the foundation, } \\
\text { headmaster, vice principal, } \\
\text { teachers. }\end{array}$ & $\begin{array}{l}\text { Chairman of the foundation, } \\
\text { headmaster, vice principal, } \\
\text { teachers. }\end{array}$ \\
\hline 3. & $\begin{array}{l}\text { Possession of coach and } \\
\text { coordinator line }\end{array}$ & $\begin{array}{l}\text { The highest coach is the } \\
\text { chairman of the } \\
\text { foundation, there is a } \\
\text { caregiver or coach in the } \\
\text { Islamic boarding school as } \\
\text { the teacher of the chairman } \\
\text { of the foundation or the } \\
\text { child of the coach. }\end{array}$ & $\begin{array}{l}\text { The highest coach is the } \\
\text { chairman of the foundation, } \\
\text { there is a caregiver or coach in } \\
\text { the Islamic boarding school as } \\
\text { the teacher of the chairman of } \\
\text { the foundation or the child of } \\
\text { the coach. }\end{array}$ & $\begin{array}{l}\text { The highest coach is the } \\
\text { chairman of the foundation, } \\
\text { there is a caregiver or coach } \\
\text { in the Islamic boarding } \\
\text { school as the teacher of the } \\
\text { chairman of the foundation } \\
\text { or the child of the coach. }\end{array}$ \\
\hline 4. & $\begin{array}{l}\text { The peak structure of leadership } \\
\text { in the higher coach }\end{array}$ & $\begin{array}{l}\text { The chairman of the } \\
\text { foundation }\end{array}$ & $\begin{array}{c}\text { The chairman of the } \\
\text { foundation }\end{array}$ & \\
\hline 5. & $\begin{array}{l}\text { The regional and geographical } \\
\text { location, distance }\end{array}$ & $\begin{array}{c}\text { Bangkalan regency, Kamal } \\
\text { district }\end{array}$ & $\begin{array}{c}\text { Bangkalan regency, Kamal } \\
\text { district }\end{array}$ & $\begin{array}{c}\text { Bangkalan regency, Kamal } \\
\text { district }\end{array}$ \\
\hline 6. & Coach & $\begin{array}{l}\text { A teacher from the } \\
\text { chairman of the foundation } \\
\text { and his son }\end{array}$ & $\begin{array}{l}\text { A teacher from the chairman of } \\
\text { the foundation and his son }\end{array}$ & $\begin{array}{l}\text { A teacher from the chairman } \\
\text { of the foundation and his son }\end{array}$ \\
\hline 7. & $\begin{array}{l}\text { Background of school } \\
\text { institution establishment }\end{array}$ & $\begin{array}{l}\text { The needs of Islamic } \\
\text { students in Islamic } \\
\text { boarding school and the } \\
\text { community around the } \\
\text { Islamic boarding school }\end{array}$ & $\begin{array}{l}\text { The needs of Islamic students } \\
\text { in Islamic boarding school and } \\
\text { the community around the } \\
\text { Islamic boarding school }\end{array}$ & $\begin{array}{l}\text { The needs of Islamic } \\
\text { students in Islamic boarding } \\
\text { school and the community } \\
\text { around the Islamic boarding } \\
\text { school }\end{array}$ \\
\hline 8. & Institution' vision and mission & Having similarities & Having similarities & Having similarities \\
\hline 9. & Teachers' background & $\begin{array}{c}\text { Teachers were the alumni, } \\
\text { cleric's family members, } \\
\text { and STKIP PGRI } \\
\text { Bangkalan }\end{array}$ & $\begin{array}{l}\text { Teachers were the alumni, } \\
\text { cleric's family members, and } \\
\text { STKIP PGRI Bangkalan }\end{array}$ & $\begin{array}{l}\text { Teachers were the alumni, } \\
\text { cleric's family members, and } \\
\text { STKIP PGRI Bangkalan }\end{array}$ \\
\hline 10. & Sources of funding & $\begin{array}{l}\text { Self-funding of Islamic } \\
\text { boarding school } \\
\text { institutions, the uncertainty } \\
\text { of donors, school } \\
\text { operational funding }\end{array}$ & $\begin{array}{l}\text { Self-funding of Islamic } \\
\text { boarding school institutions, } \\
\text { the uncertainty of donors, } \\
\text { school operational funding }\end{array}$ & $\begin{array}{l}\text { Self-funding of Islamic } \\
\text { boarding school institutions, } \\
\text { the uncertainty of donors, } \\
\text { school operational funding }\end{array}$ \\
\hline
\end{tabular}

Table 2. The source of data and the number of informants

\begin{tabular}{|c|c|c|c|c|}
\hline \multirow{2}{*}{ No } & \multirow{2}{*}{ Job titles } & \multicolumn{3}{|c|}{ Number of informants } \\
\cline { 2 - 4 } & & Nurudholam & Baburrahmah & Ngadisari \\
\hline 1. & The chairman of the foundation & 1 & 1 & 1 \\
\hline 2. & Headmaster & 1 & 1 & 1 \\
\hline 3. & Vice principal & 1 & 1 & 1 \\
\hline 4. & Supervisor & 1 & 1 & 1 \\
\hline 5. & Teacher & 2 & 2 & 2 \\
\hline 6. & Coach & 2 & 2 & - \\
\hline 7. & Stakeholder & - & 1 & 1 \\
\hline 8. & Committee & 1 & 29 & \\
\hline
\end{tabular}


The techniques of data collection employed were in-depth interviews, observations, and documentation. For the source of the data, the researcher employed snowball and purposive sampling techniques. The number of informants takes data employed by a snowball and purposive sampling techniques as seen in table 2 .

The data analysis integrated two types of model, which are Spradley, miles and Huberman. In the field, the process of the data collection process and analysis employed a qualitative analysis model. Spradley [10] states that the research process starts from the one that extends and then narrows then extends again. Using domain analysis, taxonomy, compound, and cultural themes, multi-site research in this study employed two steps or stages, the analysis was carried out on a single-site first proceeded in the cross-site analysis. The following is a single site analysis in Figure 1.

Furthermore, after the data have been under the single-site analysis, then the cross-site analysis was performed. At this point, the researchers conducted an analysis procedure in analytic induction with the procedure of qualitative data analysis, as seen in Figure 2.

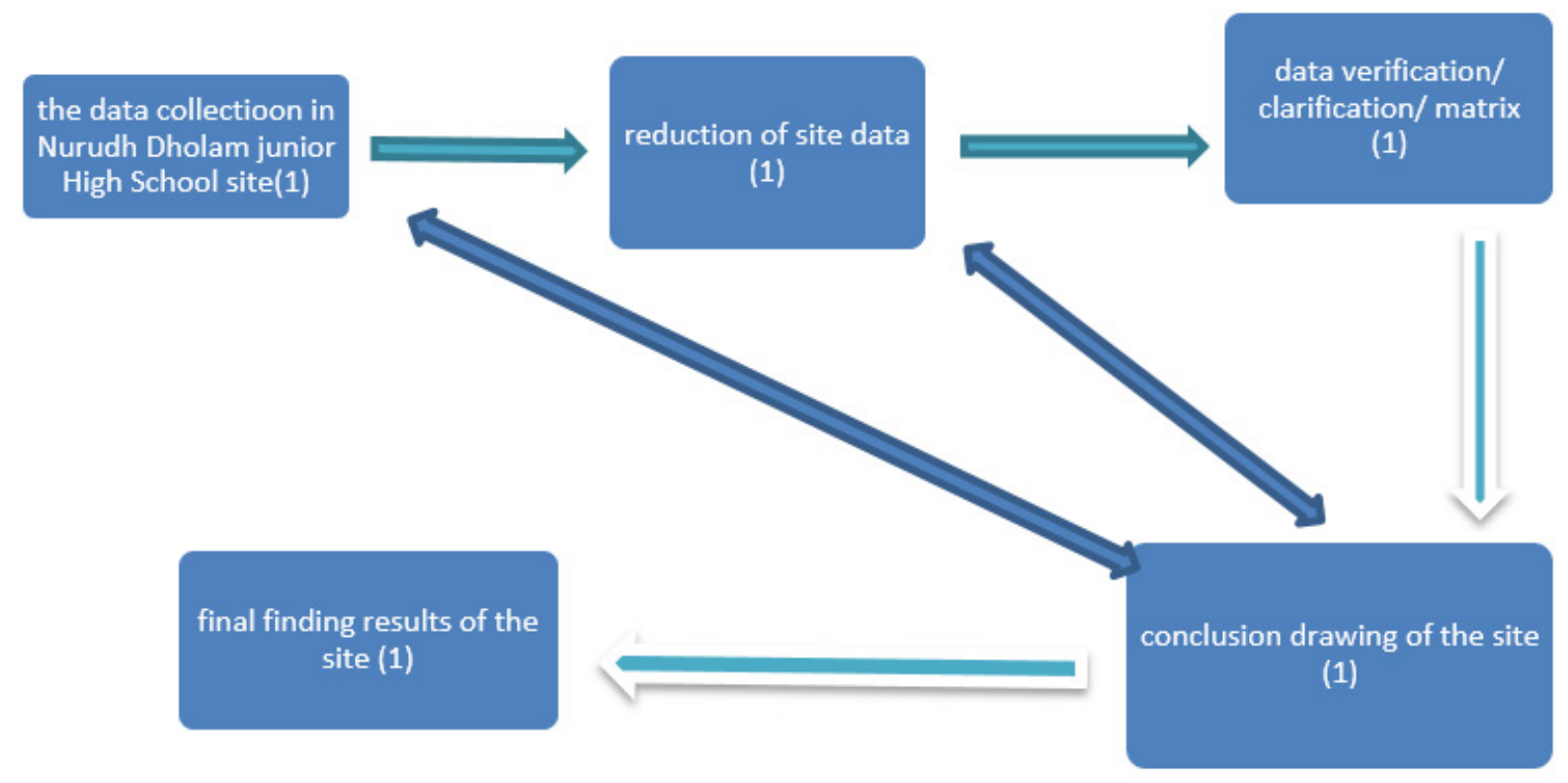

Figure 1. The procedure of single-site data analysis

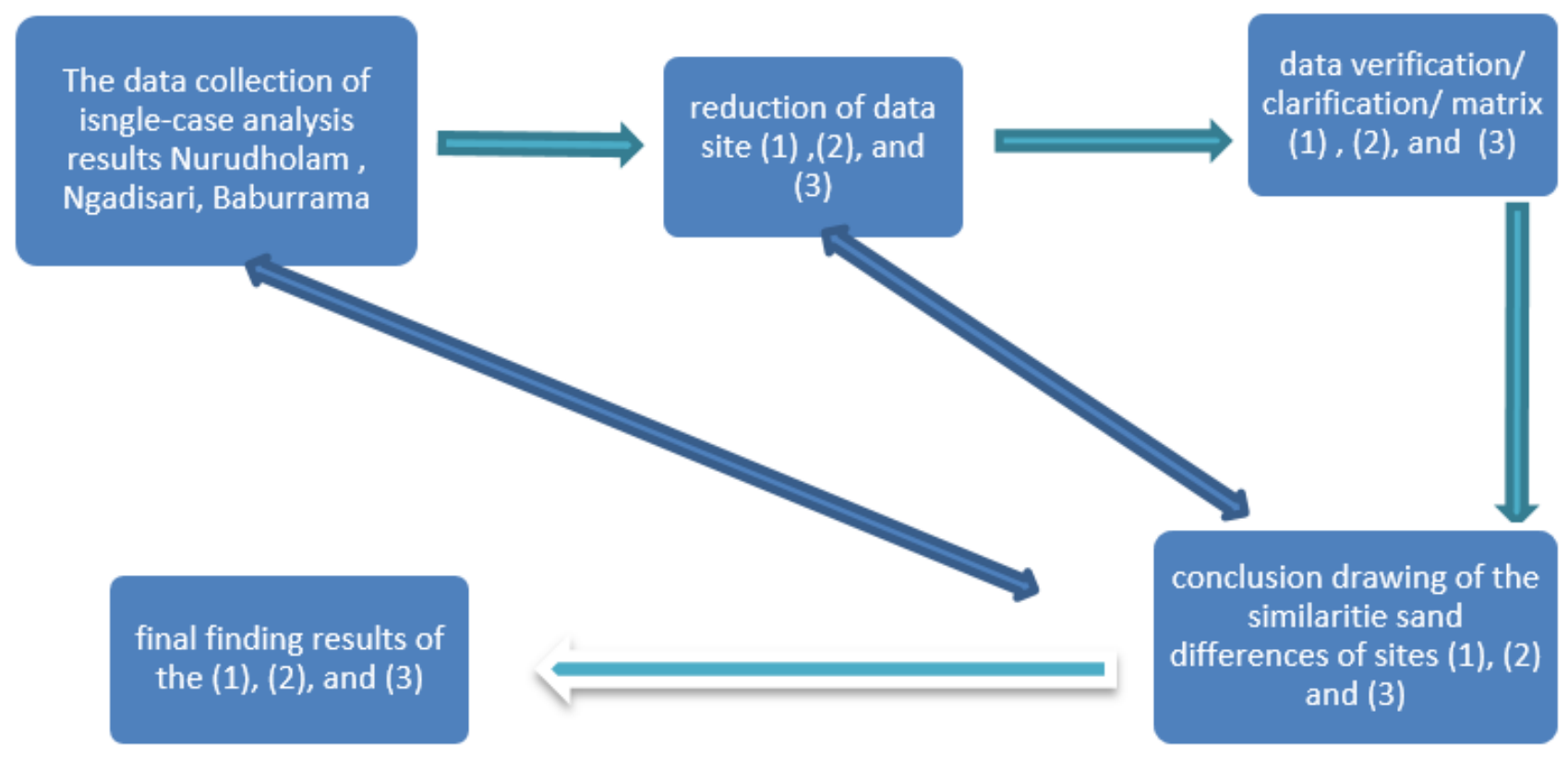

Figure 2. The procedure of cross-site data analysis 


\section{Results}

The research finding of the teacher professional development coaching based on the Islamic boarding school culture in three sites are as follows:

\subsection{The Implementations of Interaction Pattern}

\subsubsection{The Scheduled Interaction Pattern}

Regularly once a month, coaching in three sites was conducted and attended by all administrators, coaches, and teachers.

\subsubsection{The Unscheduled Interaction Pattern}

The interaction pattern performed according to the situations and conditions of the institutional activities, and the opportunities which can be conducted as coaching is as follows. (1) during the celebration of imtikhan (2) silaturahmi/get together hospitality visit was conducted in each teacher's house who is problematic or not (3) the interaction pattern was conducted after mid-day congregation prayer (4) recitation according to the religious and Islamic boarding school agenda.

During imtikhan, the celebration of one academic year, the coaching was conducted to motivate the professionalism of the teachers. Silaturrahmi was also carried out by the board of directors especially by the chairman of the foundation and the headmaster to come closer to the teacher to know the daily life as a large family of Islamic boarding school as the following data shows the existence of guidance in the form of silaturrahmi. In the opportunity to do congregational prayers, the coaching communication is carried out and discussed actively after the mid-day congregation prayer, which is often led by the chairman of the foundation. The coaching was conducted based on the explanation by the chairman of the foundation that the actual coaching was conducted each time there was an opportunity and every time. Therefore the intensity of the coaching is very intense.

\subsection{The Approaches Used in the Coaching}

There are several approaches used in the coaching, namely (1) individual approach, (2) in-group approach, (3) seniority in knowledge, and (4) the system bureaucracy owned and agreed by the educational institution.

The employed approaches depend on the types of problem generally encountered by most teachers or problems experienced by a small number of teachers or problems experienced by each teacher.

\subsection{The Involvement of Stakeholder in Conducting a Coaching}

It is found out that there is an involvement of stakeholder, even though small. There was an overlap of roles and the stakeholders' functions because the chairman of the foundation, several administrators, caregivers, and some teachers work in the educational institution

The chairman of the foundation, several teachers, and supervisors in Bangkalan Region particularly Kamal have established their religious and social figures. Moreover, young teachers have become social and youth figures in the environment where the school is located.

\subsection{Evaluation and Supervision during the Implementation of Teacher Professionalism Coaching Based on Islamic Boarding School Culture}

The evaluation and supervision were conducted by the chairman of the foundation and assisted by the school headmaster and several senior teachers. The results of the evaluation are very helpful to conduct a follow-up for those who are successful or not according to the changes in the related teachers.

There is an award given to the teachers who have succeeded or not in the coaching. The award is granted to those who have and have not reached the target. For those who are appropriate with the target, they are generally discipline and diligent then they will be given (1) a certificate, (2) additional 1 month salary, (3) for those who successfully maintain $100 \%$ attendance will be given the opportunity to teach at Baburrahma High School, and (4) assigned as a homeroom teacher. While those who have not succeeded in coaching such as lacking discipline like skipping teaching hours are not good, they will (1) get a decrease in their teaching hours, (2) be given awards, and (3) be given professional books.

The grant of awards and gifts immensely motivates the teachers, awards were given to teachers who have succeeded and have not, awards are in the form of $100 \%$ certificate of attendance, addition of class hours, appointment as homeroom teacher, provision of books, and all teachers receive a gift in the form of money.

\section{Discussion}

The research results showed that there is a correlation with some of the results of previous studies that made the development and basis of research related to the development of teacher professionalism based on Islamic boarding school culture at three Islamic high school sites, namely Nurudholam, Baburrahma Middle School, and Ngadisari Middle School Nurul Iman. Referring to Law No. 20 of 2003 Article 10, it is clear that when an educational institution is established, realizing a good quality of education cannot be separated from the coaching and funding for teachers who have shortcomings in their professionalism [11]. 


\subsection{Interaction Pattern of Teacher Professionalism Coaching on Three Sites}

The interaction pattern implemented on a schedule was conducted regularly once a month coaching in three sites attended by all chairmen of the foundation, the coaches, and even school committees and supervisors sometimes all the administrators and all school teachers are all present. The unscheduled interaction pattern is carried out as well as adjusting the situation and conditionally according to the activities of the institution and the opportunities that can be implemented coaching in the form of coaching interaction patterns utilizing warnings. (1) Imtikhan, (2) get-together hospitality visit, (3) congregation prayer, and (4) recitation according to the religious [4]. Islamic boarding school agenda show there is an interaction pattern conducted by the administrators in implementing the teacher coaching which is conducted according to organizational plans in the Islamic boarding school institution.

This is supported by the results of previous research by Hidayat [4] entitled "management of the competence of teachers in Islamic boarding schools based on Islamic boarding schools. Hidayat's research aims to find out that the results of the research show that the authority of guidance is on the headmaster of the Islamic school and the leadership of the Islamic boarding school. The implementation of coaching is carried out through an improvement program in academic qualifications, certification, integrated training, and supervision. Basic coaching activities always refer to the Sunnah of the Messenger of Allah and the traditions of al-salaf as-sālih. The evaluation of coaching was conducted on the aspect of teacher's competence. The results of the evaluation were followed up in the form of workshop, improvement, and prevention.

\subsection{Approaches Used in the Coaching}

There are several approaches used on three-site coaching, namely (1) individual approach, (2) in-group approach, (3) seniority in knowledge approach, and (4) the system bureaucracy owned and agreed by the Islamic school educational institution.

This was supported by the scientific finding by Pidarta [12] related to several techniques in conducting the approaches in the coaching among them are activities using an approach individually and in-group. Approaches in the form of supervision by influential superiors in organizations considered senior in this case can be the chairman of the foundation, the chairman of the institution, the headmaster on the teacher and personnel responsible for the learning process hoping students learn effectively and the learning achievement increases. The techniques of approaches are classroom observation, classroom visits, discussion in formal and informal meetings, or teacher meeting.

\subsection{The Involvement of Stakeholder in Conducting the Coaching}

The implementation of coaching in the involvement of stakeholders is involved even though in a small capacity, and there is an overlap of the role and function of the stakeholders. That is happened because the chairman of the foundation, some of the management, caregivers, and some teachers are stakeholders who work in the Islamic boarding school even though thus far in that region they have become religious, social and youth figures.

This is supported by Kuratko [13], which states that the leadership style as a unifying stakeholder is able to unite all elements and different potentials. It becomes a synergistic force useful for all party lies the uniqueness of leadership (management) in the Islamic boarding school world as a cleric stakeholder as an Islamic student public figure accommodating Islamic student cultural diversity, develops the traditions of helping each other in the ambiance of brotherhood between the clerics and their students.

\subsection{Evaluation and Supervision during the Implementation of Teacher Professionalism}

The implementation and supervision based on Islamic boarding school culture were conducted by the chairman of the foundation and several senior teachers. The results of the evaluation are very helpful to take follow-up actions for those who have succeeded or those who have not succeeded need to take appropriate actions with changes for the teacher in question. The results of the evaluation are very helpful to conduct a follow up for those who have succeeded or not to take the follow up according to the changes of the related teachers.

During the evaluation and supervision, the gift or award grant was also conducted for teachers who have succeeded and have not, the award given was in the form of 100 attendance certificate, additional teaching hours, assigned as homeroom teachers, being given books and books related to teachers professionalism, besides that there is an interesting aspect which is a funding of money as a bonus equals to one-month salary.

The supporting aspect from several books and research results related to evaluation was conducted by Ibrahim [14] that evaluation and supervision in teacher development are not only as of the implementation of aimless activities for changes in the teacher. Sustainable teacher coaching is expected to improve changes in the self-development, abilities, knowledge, and expertise as a professional teacher. Therefore a planned and integrated coaching system, planning, and the implementation of coaching program are needed. Figure 3 shows a conclusion for young people to understand the results in this study. 


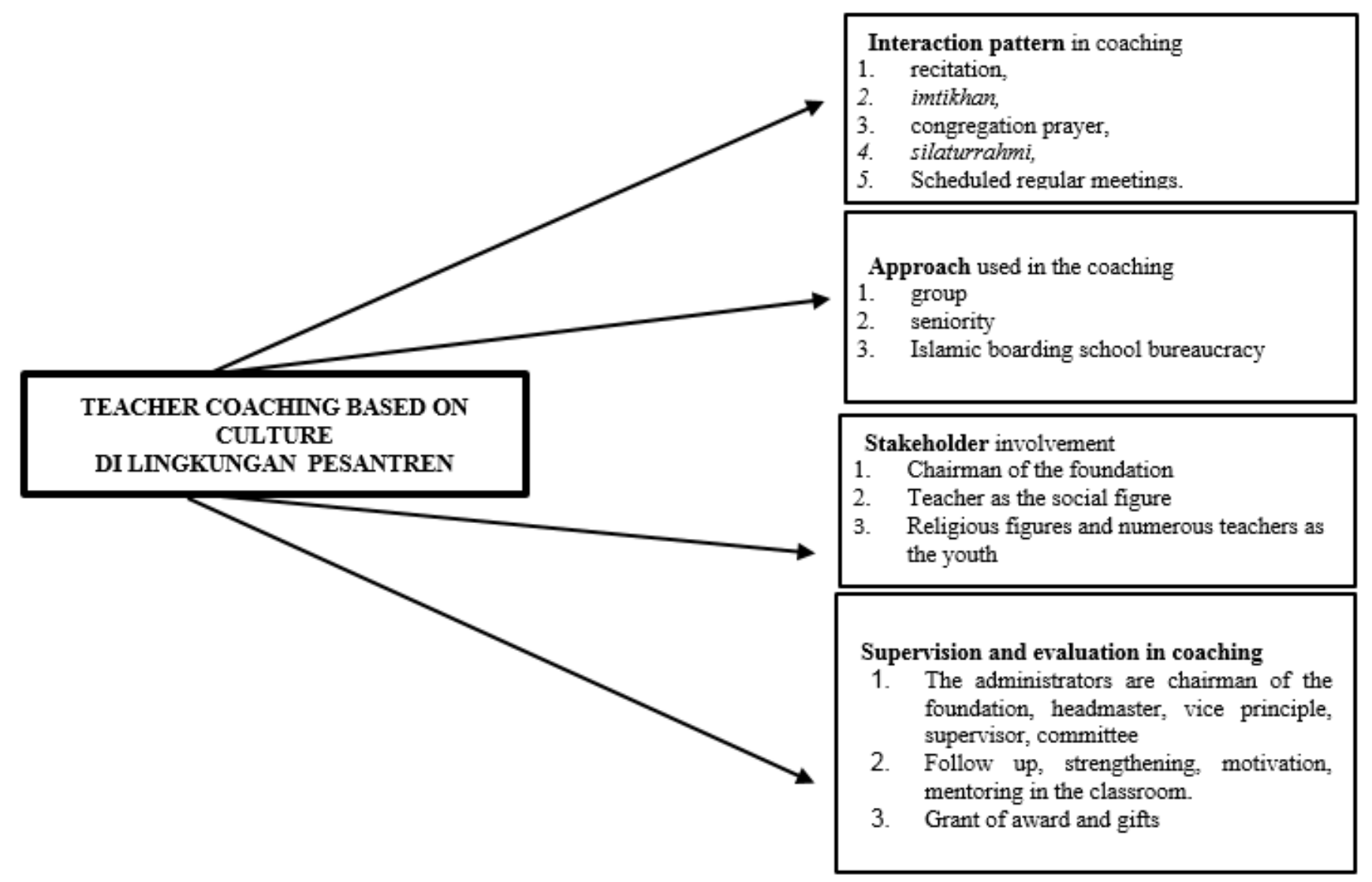

Figure 3. Conclusions of teacher coaching based on the culture in Islamic boarding school environment

\section{Conclusions}

The conclusion in this article is the information results of the explanation and experiences of the chairman of the foundation, headmaster, vice principal, school supervisor, several stakeholders, caretakers, and teachers in three Junior High Schools in Kamal district based on the research focus in three sites are as follows:

The interaction pattern has several interactions starting from Quran recitation, imtikhan, congregation prayers, get-together hospitality visits, and scheduled regular meetings. The principal vice approach used in coaching is carried out in groups, individuals, seniority, and bureaucracy or systems within the Islamic boarding school itself. The involvement of stakeholders when coaching is very ambiguous considering that as a stakeholder in each neighbourhood, each Islamic boarding school is the chairman of the foundation and several teachers as community leaders, religious leaders and many teachers as youth leaders so that the involvement of many comments is very small and forms as a supporter in coaching. Evaluation and supervision during the implementation of coaching are performed to know how far the success of the coaching is. For further shortcomings or issues, a follow-up will be performed by the chairman of the foundation and several administrators to supervise on whether the implementation has been conducted according to the objectives of the institution as well as the presence of award and gift grants.

\section{REFERENCES}

[1] R. Indonesia, "Undang-undang Republik Indonesia nomor 14 tahun 2005 tentang Guru dan Dosen," Sekretariat Negara. Jakarta, 2005.

[2] M. S. Zuhriy, "Budaya Pesantren dan Pendidikan Karakter Pada Pondok Pesantren Salaf," Walisongo: Jurnal Penelitian Sosial Keagamaan, vol. 19, pp. 287-310, 2011.

[3] R. Baya'gub, "Kompetensi Profesional Guru Madrasah Di Lingkungan Pesantren," ed: Jember: Jurnal Fenomena, 2016.

[4] W. Hidayat, "Manajemen Pembinaan Kompetensi Guru Madrasah Aliyah Berbasis Pesantren," Jurnal Pendidikan Islam UIN Sunan Gunung Djati, vol. 28, pp. 21-39, 2013.

[5] A. S. Rizal, "Pendidikan Nilai Secara Active-Learning Dalam Tradisi Pondok Pesantren," Jurnal Pendidikan Agama Islam-Ta'lim, vol. 10, pp. 1-12, 2012.

[6] J. Suteja, "Peran kyai dalam pembinaan mental spiritual santri remaja di pondok pesantren kota cirebon (Studi Multisitus di Pondok Pesantren Jagasatru, Al-Istiqomah, Ulumuddin, dan Madinatunnajah Kota Cirebon)," ORASI: 
Jurnal Dakwah dan Komunikasi, vol. 6, 2017.

[7] R. Depag, "Standar Kompetensi Madrasah Ibtidaiyah," ed: Jakarta: Dirjen Kelembagaan Agama Islam, 2004.

[8] I. Sulaiman, "Masa depan pesantren; Eksistensi pesantren di tengah gelombang modernisasi," Malang: Madani, 2010.

[9] R. Bogdan and S. Biklen, "Qualitative research/or education: An in - troduction to theory and methods," Needharn Heights, MA: Allyn \& Bacon, 1992.

[10] J. Spradley, "Participation, Observation, Holt Rinehart and Wiston," ed: New York, 1980.

[11] U.-U. R. I. Nomor, "tahun 2003 tentang Sistem pendidikan Nasional," ed.

[12] I. M. Pidarta, Landasan Kependidikan Stimulus Ilmu Pendidikan Bercorak Indonesia, Jakarta: PT. Bina Rineka Cipta, 1997.

[13] D. F. Kuratko, "Entrepreneurial leadership in the 21st century: Guest editor's perspective," Journal of Leadership \& Organizational Studies, vol. 13, pp. 1-11, 2007.

[14] B. Ibrahim, "Peningkatan Profesionalisme Guru Sekolah Dasar," Jakarta: Bumi Aksara, 2004. 